\title{
Biomonitoring of air borne metal pollution
}

\author{
M. Lodenius \\ Department of Environmental Sciences, University of Helsinki, Finland
}

\begin{abstract}
Mosses, lichens and vascular plants may be used for monitoring airborne pollution, e.g. wet and dry deposition of metals in polluted areas. Best results are achieved when using transplantation methods including exposure for a certain period of time. Spreading of metals around point sources can be followed with great accuracy. Often at least semi quantitative estimates of deposition can be made. Biomonitoring methods are cheap and efficient but relations to results achieved by technical methods should be evaluated in more detail.
\end{abstract}

Keywords: metal pollution, deposition, biomonitoring, moss, lichen, plant.

\section{Introduction}

Monitoring of air borne pollutants may be carried out by using mechanical devices or biological organisms aiming at local, regional or global monitoring of atmospheric deposition. Nowadays biomonitoring methods are widely used around the world. Biological and technical methods are different and do not necessarily measure the same things. Biological methods are cheap and easy to use and they may be passive (primarily spatial distribution) or active (spatial and temporal distribution). Biological methods have many advantages but there are still lots of uncertainties when estimating actual deposition of metals. By using combinations of mechanical and biological methods it is possible to compare results representing different approaches in the same area.

\section{Biomonitoring methods and approaches}

\subsection{Epiphytic lichens}

The presence or absence of certain species of epiphytic lichens has for long been used as indicators of air quality $[1,2]$. Lichens have also been widely used as 
indicators of spatial distribution of metal pollution. Lichens are perennial, symbiotic organisms including a fungal part (usually Ascomycetes) and an algal part (Chlorophyceae or Cyanobacteriae). The structure of the lichen thallus makes it suitable for uptake of both particles and gaseous compound directly from the atmosphere. In absence of cuticle and stoma the uptake is evenly distributed in the organism. As most lichens are capable of accumulating metals even from very low concentrations in the air, they can be used as efficient indicators of air quality [3].

Air pollution may harm epiphytic lichens which is a disadvantage when planning air quality surveys. Many species are e.g. sensitive to sulfur oxides and particulates [4]. In the vicinity of a copper mine Branquinho et al. [5] reported also toxic effects of $\mathrm{Cu}$ on the lichen Ramalina fastigiata. Naturally, lichens that are absent or show limited growth cannot be used for monitoring of element distribution.

Many species have been successfully used for monitoring purposes, e.g. Hypogymnia physodes, Evernia prunastri, Ramalina farinacea. Distribution patterns of heavy metals can reveal hot spot areas and point sources [6-8]. Often metal distribution in epiphytic lichens can be explained by land use, such as urban and industrial areas, traffic and green areas etc. [9]. Epiphytic lichens have also been used for country-wide or regional surveys of metal pollution [10-12]. A list of concentrations of heavy metals measured from different epiphytic lichens is given by Conti and Cecchetti [2].

\subsection{Terrestrial mosses}

Terrestrial mosses often form a green mat on the forest floor especially in boreal forests. These bryophytes do not have a root system or leaf cuticula. They have high surface-to-volume ratio and high cation exchange capacity of cell walls. The affinity to different metals is not necessarily the same for different metals which means that metal proportions do not exactly reflect proportions in deposition. However, Rühling et al. [13] calculated a rough relation: concentration in moss $\left(\mathrm{mg} \mathrm{x} \mathrm{kg}{ }^{-1} \mathrm{~d} . \mathrm{w}.\right)=4 \times$ atmospheric deposition $\left(\mathrm{mg} \mathrm{x} \mathrm{m}{ }^{-2}\right.$

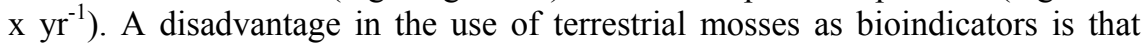
they in northern countries are covered by snow in winter time. Several species have been used as biomonitors, e.g. Hylocomium splendens, Pleurozium schreberi, Hypnum cupressiforme and Scleropodium purum. The parts used for analysis are usually 1-3 years old. The glittering wood-moss $H$. splendens can be divided into segments each representing one year's growth. The procedure is somewhat laborious but gives valuable additional information about the deposition.

Terrestrial mosses have been used for monitoring metal emissions from road traffic [14] and industries [15, 16]. Fernández et al. [17] proposed a method using terrestrial mosses (Pseudoscleropodium purum) where it is possible to get a good picture of the metal distribution based on a limited number of samples.

Surveys of long-range transboundary pollution analysed by means of moss analyses are convincing examples of the use of terrestrial mosses for biomonitoring $[18,19]$. In the European moss survey carried out every five years 
[20] maps covering most of Europe clearly show the spatial distribution of twelve metals. The concentrations of some metals (As, Cr, V and $\mathrm{Zn}$ ) are higher in southern Europe compared to northern and central Europe (Table 1). Although different species and different analytical methods are applied in different countries, detailed instructions and intercalibrations ensure reliable and comparable results.

Table 1: Ranges of median concentrations $\left(\mathrm{mg} \mathrm{kg}^{-1}\right)$ for some metals in countries of northern, central and southern Europe; data from [20].

\begin{tabular}{|c|c|c|c|}
\hline & Northern Europe & Central Europe & Southern Europe \\
\hline $\mathrm{As}$ & $0.07-0.90$ & $0.12-0.90$ & $0.18-1.7$ \\
\hline $\mathrm{Cd}$ & $0.05-0.50$ & $0.09-0.50$ & $0.08-0.31$ \\
\hline $\mathrm{Cr}$ & $0.58-6.8$ & $0.82-6.8$ & $2.4-6.5$ \\
\hline $\mathrm{Cu}$ & $2.8-15$ & $3.6-15$ & $6.2-11$ \\
\hline $\mathrm{Fe}$ & $120-2200$ & $260-2200$ & $350-2300$ \\
\hline $\mathrm{Hg}$ & $0.04-0.14$ & $0.03-0.14$ & $0.05-0.07$ \\
\hline $\mathrm{Ni}$ & $0.61-5.8$ & $0.78-5.8$ & $2.9-4.4$ \\
\hline $\mathrm{Pb}$ & $1.4-15$ & $2.6-15$ & $2.3-17$ \\
\hline $\mathrm{V}$ & $0.87-6.4$ & $0.67-6.4$ & $1.5-6.3$ \\
\hline $\mathrm{Zn}$ & $17-77$ & $20-77$ & $28-37$ \\
\hline
\end{tabular}

\subsection{Tree bark}

When using tree bark samples are collected from the same height (e.g. 1.5-1.7 m above the ground) from several trees (e.g. 5-25 parallel samples) from spots that are free from epiphytic organisms. The trees are normally of the same species (e.g. Scots pine; Pinus sylvestris L.) and of similar age. Concentrations in ash are generally rather low but they reflect the load of atmospheric pollution and are cost-effective [21, 22].

Schulz et al. [23] analysed a considerable amount of metals and other pollutants in two different years from bark of Scots pine in eastern Germany and concluded that bark can characterize spatial and temporal variation in deposition of airborne organic and inorganic pollutants. Based on a nation-wide monitoring of heavy metals Lippo et al. [24] considered bark of Scots pine to be suitable as biomonitor although mosses and epiphytic lichens revealed regional differences better. In a Czech survey [25], oak bark proved to be a good tool in identifying the origin of atmospheric pollutants and mapping the spatial distribution of metals. 


\subsection{Leaves}

Plant leaves have been used in many biomonitoring studies but they are not easy to compare because widely different species have been used. The surface of leaves vary from thick, smooth and waxy surfaces to very thin and hairy leaves. E.g. in a comparison between Finland and Slovenia great differences were found between species in both contaminated and uncontaminated areas [26]. In addition there may be seasonal variations in metal concentration of plant leaves [27] which affect the interpretation of results. Remon et al. [28] analyzed both total and ammonium acetate-EDTA extractable metal concentrations in plant communities and concluded that more attention should be paid to analyzing metal availability and that plant communities represent a more realistic approach compared to sampling of a single species.

As mercury to a great extent occur in gaseous form in the atmosphere and the translocation of this metal within the plant is negligible, the concentrations in leaves may be used as a quantitative measure of atmospheric deposition [29]. Both Rye grass (Lolium perenne) and moss (Sphagnum girgensohnii) have been shown to efficiently absorb atmospheric mercury at different temperatures. The sorption is strong with almost no losses even at high temperatures (up to $+60^{\circ} \mathrm{C}$ ) [15].

In Turkey Celik et al. [30] used leaves of Robinia pseudo-acacia and found that they well reflected industrial and traffic-related pollution of $\mathrm{Fe}, \mathrm{Zn}, \mathrm{Pb}, \mathrm{Cu}$, $\mathrm{Mn}$ and $\mathrm{Cd}$. Of these metals $\mathrm{Cu}$ and $\mathrm{Pb}$ were primarily related to traffic and the other metals to industrial sites. Washing of the samples removed metals from the leaf surfaces but at different degree for different metals.

\subsection{Conifer needles}

Coniferous needles have some advantages as bioindicators: they are easy to collect and it is possible to differentiate between needles of different age. Although the uptake of metals usually is rather weak and the concentrations low they can still be used as biomonitors of atmospheric metal pollution [31]. Studying the longevity of pine needles in the vicinity of pollution sources and Lamppu and Huttunen [32] found a significant negative correlation between the longevity and concentrations of heavy metals. The distribution of elements within conifer needles may be uneven [33] but this does not pose any problem when samples of whole needles are homogenized. Old trees usually accumulate heavy metals at a higher rate than younger trees (Cedrus libani) [34]. Comparing samples of current and previous years' needles, moss (Pleurozium schreberi) and pine bark (Pinus sylvestris) as biomonitors of industrial pollution and SameckaCymerman et al. [35] found needles to be good indicators for $\mathrm{Cu}, \mathrm{Zn}, \mathrm{Mn}$ and $\mathrm{Ni}$.

\subsection{Temporal aspects and transplant techniques}

In order to estimate changes in metal deposition it is possible to repeat sampling and analysis regularly or use transplant methods where living organisms are 
analysed before and after moving them to the study area. Transplant methods are useful e.g. in areas where natural bioindicators are lacking [36]. Spatial and temporal trends in metal deposition have been revealed and accurately mapped by using systematically repeated sampling of mosses [37, 38]. Giordano et al. [39] compared bags of mosses (Sphagnum capillifolium) and lichens (Pseudevernia furfuracea) and found in general stronger accumulation in Sphagnum than in Pseudevernia. Metal uptake did not follow exactly the same pattern in mosses and lichens. Studying transplants of lichens (Evernia prunastri) Ayrault et al. [40] found that the trace metal concentrations were not homogeneously distributed within the thallus but rather concentrated to the cortex. Also transplants of vascular plants like the epiphytic Tillandsia capillaris have been used for biomonitoring purposes [41].

In some cases analyses of tree rings have been used for assessing temporal changes in metal exposure [42-44]. Long-term changes can be studied also by using herbarium samples. In northern England $\mathrm{Pb}$ and $\mathrm{Cu}$ in mosses are thought to derive primarily from atmospheric deposition with highest levels in the late 19th century [45]. The origin of $\mathrm{Ni}$ and As is primarily soil. When using herbarium samples special attention must be paid to possible contamination during storage. Calzoni et al. [46] used perennial shrub Rosa rugosa as an active biomonitor of heavy metal pollution. The plants were placed in flower beds (16 $\mathrm{m}^{2}$ in size; 16 specimens per site) and analyzed after one year. The heavy metal concentrations in leaves reflected the pollution patterns and concentrations in soil.

The moss bag technique has been increasingly used for monitoring of heavy metals and other pollutants. Moss is collected, purified and placed in nylon nets in trees throughout the study area for a certain period of time (often 1-2 months). Although air pollutants may damage exposed transplants (lichens or mosses) [47, 48] they are still capable of taking up metals from the atmosphere. The most common species used in moss bags are mosses from the genus Sphagnum but also other species like Hylocomium splendens, Pleurozium schreberi and Hypnum spp. have been used [16, 36]. A study in Shanghai [49] showed that moss bags with Haplocladium microphyllum is a simple, inexpensive and useful technique for biomonitoring of $\mathrm{S}, \mathrm{Cu}, \mathrm{Pb}$, and $\mathrm{Zn}$. The concentrations were significantly higher after 1 month's exposure and were usually a little lower after two and three month's exposure. In addition to sorption of metals to moss tissue also desorption (leaching and evaporation) should be considered when estimating net deposition. In an experiment using covered and uncovered moss bags $2 / 3$ of mercury deposition was estimated to originate from dry deposition and the rest from wet deposition [50]. Also for other metals higher proportion have been found for dry deposition than via bulk deposition when using transplants of terrestrial moss (Scleropodium purum) [51]. In a review of studies applying the moss bag technique for biomonitoring purposes Ares et al. [52] have proposed standardized procedures which could give better comparability. 


\subsection{Assessment of deposition}

An important goal for biomonitoring is to quantitatively or at least semiquantitatively estimate the deposition of metals. Berg and Steinnes [53] compared data for 48 elements in ground growing mosses (Hylocomium splendens and Pleurozium schreberi) with wet deposition data and calculated regression equations for transforming moss concentration data to absolute deposition. For most metals there was a significant correlation between wet deposition and concentration in these two moss species. Based on the surface covered by moss on the ground Lodenius and Tulisalo [36] estimated quantitatively the mercury deposition around a chlor-alkali factory using moss bags of Sphagnum moss. An example of estimated deposition of mercury based on the moss bag technique is given in Table 2 .

Table 2: $\quad$ Net deposition of mercury near a pollution source estimated by using moss bags; wet deposition was calculated by subtracting dry deposition from total deposition [50].

\begin{tabular}{|l|c|}
\hline Deposition & ng Hg g \\
\hline Dry & $84 \pm 15$ \\
\hline Wet & $42 \pm 26$ \\
\hline Total & $126 \pm 20$ \\
\hline
\end{tabular}

Bulk deposition can be collected using standardized gauges but they do not necessarily reflect deposition and/adsorption on biological surfaces. Natural ecosystems are extremely diverse and complex systems including thousands of different biological surfaces which not easily can be compared to technical devices like bulk deposition collectors. The moss bag method is cheap and convenient but much more research and intercalibrations are required before we get reliable quantitative estimates of deposition.

\section{Conclusions and challenges}

Dry and wet deposition of metals depends on climatic factors (winds, temperature, rainfall etc.) and structure of receiving surfaces (e.g. water or biological organisms). Natural ecosystems are complex including a great number of biological species with very variable surfaces. In addition, sorption and leaching ability is different for different metals. Biological methods probably reflect more closely actual deposition to land surfaces than standardized mechanical collectors and instruments.

Release processes (leaching and evaporation) from biological materials should be taken in account when calculating net deposition of metals. Results obtained by using technical and biological methods are not directly comparable [54]. The following aspects should be considered in biomonitoring studies: 
- Biological monitors give a good picture of spatial and temporal distribution of metals and are valid instruments for evaluation air quality.

- There is a wide variety of sensitive biomonitoring methods which usually are cheap and convenient; they give in general reliable and repeatable results.

- The surfaces of biological materials are closer to natural ecosystems compared to technical devices, but differ widely between species.

- Because of morphological and physiological differences mosses and lichens cannot be interchangeably used as biomonitors of metal deposition [55].

- There are different deposition patterns (e.g. anthropogenic and natural emission sources) in different areas; also climatic and seasonal factors differ.

- Contribution from sources other than air pollution, e.g. marine influence, soil dust, and root uptake in higher plants must also be considered [56].

- Quantitative estimates of atmospheric deposition should be further developed bearing in mind that the results may differ depending on species, type of vegetation, season and climate.

- Much more comparisons and intercalibrations between different methods are needed.

- International standardization of biomonitoring methods is a good goal but we need a better understanding of biological, chemical and physical processes in the sorption of metals from the atmosphere to biota.

\section{References}

[1] Nylander, W., Les lichens de Jardin du Luxembourg. Bulletin de la Societé Botanique de France 13, pp. 364-372, 1866.

[2] Conti, M.E. \& Cecchetti, G., Biological monitoring: lichens as bioindicators of air pollution assessment - a review. Environmental Pollution 114, pp. 471-492, 2001.

[3] Kularatne, K.I.A. \& de Freitas C.R., Epiphytic lichens as biomonitors of airborne heavy metal pollution. Environmental and Experimental Botany 88, pp. 24-32, 2013.

[4] Lackovicova, A., Guttova, A., Backor, M., Pišút, P. \& Pišút, I., Response of Evernia prunastri to urban environmental conditions in Central Europe after the decrease of air pollution. Lichenologist, 45(1), pp. 89-100, 2013.

[5] Branquinho, C., Catarino, F., Brown, D.H., Pereira, M.J. \& Soares, A., Improving the use of lichens as biomonitors of atmospheric metal pollution. Science of the Total Environment 232, pp. 67-77, 1999. 
[6] Nimis, P.L., Lazzarin, U.G., Lazzarin, A. \& Skert, N., Biomonitoring of trace elements with lichens in Veneto (NE Italy). Science of the Total Environment, 255, pp. 97-111, 2000.

[7] Aznar, J.-C., Richer-Laflèche, M. \& Cluis, D., Metal contamination in the lichen Alectoria sarmentosa near the copper smelter of Murdochville, Québec. Environmental Pollution 156, pp. 76-81, 2008.

[8] Saunier, J.-B., Losfeld, G., Freydier, R. \& Grison, C., Trace elements biomonitoring in a historical mining district (les Malines, France). Chemosphere 93, pp. 2016-2023, 2013.

[9] Lodenius, M., Kiiskinen, J. \& Tulisalo, E., Metal levels of an epiphytic lichen as indicators of air quality in a Finnish suburb metals. Boreal Environment Research, 15, pp. 446-452, 2010.

[10] Lodenius, M., Regional distribution of mercury in Hypogymnia physodes in Finland. Ambio 10, pp. 183-184, 1981.

[11] Jeran, Z., Mrak, T., Jaćimović, R., Batič, F., Kastelec, D., Mavsar, R. \& Simončič, P., Epiphytic lichens as biomonitors of atmospheric pollution in Slovenian forests. Environmental Pollution 146, 324-331, 2007.

[12] Rossbach, M., Jayasekera, R., Kniewald, G. \& Thang, N.G., Large scale air monitoring: lichen vs. air particulate matter analysis. Science of the Total Environment 232, pp. 59-66, 1999.

[13] Rühling, Å., Rasmussen, L., Pilegaard, R., Mäkinen, A. \& Steinnes, E., Survey of atmospheric heavy metal deposition. Nord, Nordic Council of Ministers 21, 44 p., 1987.

[14] Zechmeister, H.G., Hohenwallner, D., Riss, A. \& Hanus-Illnar, A., Estimation of element deposition derived from road traffic sources by using mosses. Environmental Pollution 138, pp. 238-249, 2005.

[15] Lodenius, M., Tulisalo, E. \& Soltanpour-Gargari, A., Exchange of mercury between atmosphere and vegetation under contaminated conditions. Science of the Total Environment, 304, pp. 169-174, 2003.

[16] Fernández, J.A., Aboal, J.R. \& Carballeira, A., Identification of pollution sources by means of moss bags. Ecotoxicology and Environmental Safety 59, pp. 76-83, 2004.

[17] Fernández, J.A., Aboal, J.R., Real, C. \& Carballeira, A., A new moss biomonitoring method for detecting sources of small scale pollution. Atmospheric Environment 41, pp. 2098-2110, 2007.

[18] Šakalys, J., Kvietkus, K., Sucharová, J., Suchara, I., \& Valiulis, D., Changes in total concentrations and assessed background concentrations of heavy metals in moss in Lithuania and the Czech Republic between 1995 and 2005. Chemosphere 76, pp. 91-97, 2009.

[19] Poikolainen, J., Kubin, E., Piispanen, J. \& Karhu, J., Estimation of the Long-range Transport of Mercury, Cadmium, and Lead to Northern Finland on the Basis of Moss Surveys. Arctic, Antarctic, and Alpine Research, 36(3), pp. 292-297, 2004.

[20] Harmens, H, Norris, D., Mills, G. and the participants of the moss survey, Heavy metals and nitrogen in mosses: spatial patterns in 2010/2011 and 
long-term temporal trends in Europe. ICP Vegetation Programme Coordination Centre, 63 p., 2013.

[21] Schelle, E., Rawlins, B.G., Lark, R.M., Webster, R., Staton, I. \& McLeod, C.W., Mapping aerial metal deposition in metropolitan areas from tree bark: A case study in Sheffield, England. Environmental Pollution 155, 164-173, 2008.

[22] Saarela, K.-E., Harju, L., Rajander, J., Lill, J.-O., Heselius, S.-J., Lindroos, A. \& Mattsson, K., Elemental analyses of pine bark and wood in an environmental study. Science of the Total Environment 343, pp. 231-241, 2005.

[23] Schulz, H., Popp, U.P., Huhn, G., Stärk, H.-J. \& Schüürmann, G., Biomonitoring of airborne inorganic and organic pollutants by means of pine tree barks. I. Temporal and spatial variations. Science of the Total Environment 232, pp. 49-58, 1999.

[24] Lippo, H., Poikolainen, J. \& Kubin E., The use of moss, lichen and pine bark in the nationwide monitoring of atmospheric heavy metal deposition in Finland. Water, Air and Soil Pollution 85, pp. 2241-2246, 1995.

[25] Böhm, P., Wolterbeek, H., Verburg, T. \& Musílek, L. The use of tree bark for environmental pollution monitoring in the Czech Republic. Environmental Pollution 102, 243-250, 1998.

[26] Lodenius, M., Nuorteva, P. \& Nuorteva, S.-L., Mercury in vascular, terrestrial plants - Comparison between Finland and Slovenia in the years 1979-1981. Acta Universitatis Carolinae, Environmentalica 19, pp. 91-96, 2005.

[27] Lodenius, M., Seasonal variations in cadmium concentrations of plant leaves. Bulletin of Environmental Contamination and Toxicology, 69, pp. 320-322, 2002.

[28] Remon, E., Bouchardon, J.-L., Le Guédard, M., Bessoule, J.-J., Conord, C. \& Faure, O., Are plants useful as accumulation indicators of metal bioavailability? Environmental Pollution 175, pp. 1-7, 2013.

[29] Mélières, M.-A, Pourchet, M., Charles-Dominique, P. \& Gaucher, P., Mercury in canopy leaves of French Guiana in remote areas. Science of the Total Environment 311, pp. 261-267, 2003.

[30] Celik, A., Kartal, A.A., Akdoğan, A. \& Kaska, Y., Determining the heavy metal pollution in Denizli (Turkey) by using Robinio pseudo-acacia L. Environment International 31, pp. 105-112, 2005.

[31] Lodenius, M., \& Laaksovirta, K., Mercury content of Hypogymnia physodes and pine needles affected by a chlor-alkali works at Kuusankoski, SE Finland. Annales Botanici Fennici 16, pp. 7-10, 1979.

[32] Lamppu, J. \& Huttunen, S., Relations between Scots pine needle element concentrations and decreased needle longevity along pollution gradients. Environmental Pollution 122, pp. 119-126, 2003.

[33] Kuang, Y.W., Wen, D.Z., Zhou, G.Y. \& Liu, S.Z., Distribution of elements in needles of Pinus massoniana (Lamb.) was uneven and affected by needle age. Environmental Pollution 145, pp. 730-737, 2007. 
[34] Onder, S. \& Dursun, S., Air borne heavy metal pollution of Cedrus libani (A. Rich.) in the city centre of Konya (Turkey). Atmospheric Environment 40, pp. 1122-1133, 2006.

[35] Samecka-Cymerman, A., Kosiora, G. \& Kempers, A.J., Comparison of the moss Pleurozium schreberi with needles and bark of Pinus sylvestris as biomonitors of pollution by industry in Stalowa Wola (southeast Poland). Ecotoxicology and Environmental Safety 65, pp. 108-117, 2006.

[36] Lodenius, M. \& Tulisalo, E., Environmental mercury contamination around a Finnish chlor-alkali plant. Bulletin of Environmental Contamination and Toxicology 32, pp. 439-444, 1984.

[37] Harmens, H., Norris, D.A., Steinnes, E., Kubin, E., Piispanen, J., Alber, R., Aleksiayenak, Y., Blum, Y., Coskun, Y., Damh, M., De Temmerman, L., Fernández, J.A., Frolova, M., Frontasyeva, M., González-Miqueom, L., Grodzinska, K., Jeran, Z., Korzekwa, S., Krmar, M., Kvietkus, K., Leblond, S., Liiv, S., Magnússon, S.H., Mankovská, B., Pesch, R., Rühling, Å., Santamariam, J.M., Schröder, W., Spiric, Z., Suchara, I., Thöni, L., Urumov, V., Yurukova, L. \& Zechmeister, H.G., Mosses as biomonitors of atmospheric heavy metal deposition: Spatial patterns and temporal trends in Europe. Environmental Pollution 158, pp. 3144-3156, 2010.

[38] Faus-Kessler, T., Dietl, U.C., Tritschler, J. \& Peichl, L., Temporal and spatial trends of metal contents of Bavarian mosses Hypnum cupressiforme. Science of the Total Environment 232, pp. 13-25, 1999.

[39] Giordano, S., Adamo, P., Sorbo, S. \& Vingiani, S., Atmospheric trace metal pollution in the Naples urban area based on results from moss and lichen bags. Environmental Pollution 136, pp. 431-442, 2005.

[40] Ayrault, S., Clochiatti, R., Carrot, F., Daudin, L. \& Bennett, J.P., Factors to consider for trace element deposition biomonitoring surveys with lichen transplants. Science of the Total Environment 372, pp. 717-727, 2007.

[41] Goix, S., Resongles, E., Point, D., Oliva, P., Duprey, J.L., de la Galvez, E., Ugarte, L., Huayta, C., Prunier, J., Zouiten, C. \& Gardon, J., Transplantation of epiphytic bioaccumulators (Tillandsia capillaris) for high spatial resolution biomonitoring of trace elements and point sources deconvolution in a complex mining/smelting urban context. Atmospheric Environment 80, pp. 330-341, 2013.

[42] Cheng, Z., Buckley, B.M, Katz, B., Wright, W., Bailey, R., Smith, K.T., Li, J., Curtis, A. \& van Geen, A., Arsenic in tree rings at a highly contaminated site. Science of the Total Environment 376, pp. 324-334, 2007.

[43] Nabais, C., Freitas, H. \& Hagemeyer, J., Dendroanalysis: a tool for biomonitoring environmental pollution? Science of the Total Environment 232, pp. 33-37, 1999.

[44] Lageard, J.G.A., Howell, J.A., Rothwell, J.J. \& Drew, I.B., The utility of Pinus sylvestris L. in dendrochemical investigations: Pollution impact of lead mining and smelting in Darley Dale, Derbyshire, UK. Environmental Pollution 153, pp. 284-294, 2008. 
[45] Shotbolt, L., Büker, P. \& Ashmore, M.R., Reconstructing temporal trends in heavy metal deposition: Assessing the value of herbarium moss samples. Environmental Pollution 147, pp. 120-130, 2007.

[46] Calzoni, G.L., Antognoni, F., Pari, E., Fonti, P., Gnes, A. \& Speranza, A., Active biomonitoring of heavy metal pollution using Rosa rugosa plants. Environmental Pollution 149, pp. 239-245, 2007.

[47] Tretiach, M., Adamo, P., Bargagli, R., Baruffo, L., Carletti, L., Crisafulli, P., Giordano, S., Modenesi, P., Orlando, S. \& Pittao, E., Lichen and moss bags as monitoring devices in urban areas. Part I: Influence of exposure on sample vitality. Environmental Pollution 146, pp. 380-391, 2007.

[48] Adamo, P., Crisafulli, P., Giordano, S., Minganti, V., Modenesi, P., Monaci, F., Pittao, E., Tretiach, M. \& Bargagli, R., Lichen and moss bags as monitoring devices in urban areas. Part II: Trace element content in living and dead biomonitors and comparison with synthetic materials. Environmental Pollution 146, pp. 392-399, 2007.

[49] Cao, T., Wang, M., Ana, L., Yu, Y., Lou, Y., Guo, S., Zuo, B., Liu, Y., Wu, J., Cao, Y. \& Zhu, Z., Air quality for metals and sulfur in Shanghai, China, determined with moss bags. Environmental Pollution 157, pp. 1270-1278, 2009.

[50] Lodenius, M., Dry and wet deposition of mercury near a chlor-alkali plant. Science of the Total Environment, 213, pp. 53-56, 1998.

[51] Couto, J.A., Aboal, J.R., Fernández, J.A. \& Carballeira, A., Active biomonitoring of element uptake with terrestrial mosses: a comparison of bulk and dry deposition. Science of the Total Environment 324, pp. 211222, 2004.

[52] Ares, A., Aboal, J.R., Carballeira, A., Giordano, S., Adamo, P. \& Fernández, J.A., Moss bag biomonitoring: A methodological review. Science of the Total Environment 432, 143-158, 2012.

[53] Berg, T., Steinnes, E., Use of mosses (Hylocomium splendens and Pleurozium schreberi) as biomonitors of heavy metal deposition: from relative to absolute deposition values. Environmental Pollution 98, pp. 61-71, 1997.

[54] Lodenius M., Use of plants for biomonitoring of airborne mercury in contaminated areas. Environmental Research 125, pp. 113-123, 2013.

[55] Bargagli, R., Monaci, F., Borghini, F., Bravi, F. \& Agnorelli, C., Mosses and lichens as biomonitors of trace metals. A comparison study on Hypnum cupressiforme and Parmelia caperata in a former mining district in Italy. Environmental Pollution 116, pp. 279-287, 2002.

[56] Steinnes, E., A critical evaluation of the use of naturally growing moss to monitor the deposition of atmospheric metals. Science of the Total Environment 160/161, pp. 243-249, 1995. 